\title{
DILUTED ACID PRETREATMENT OF PINUS RADIATA FOR BIOETHANOL PRODUCTION USING IMMOBILIZED SACCHAROMYCES CEREVISIAE IR2-9 IN A SIMULTANEOUS SACCHARIFICATION AND FERMENTATION PROCESS
}

\author{
HERIBERTO FRANCO, ${ }^{a, b}$ REGIS TEIXEIRA MENDONÇA, ${ }^{a, b, *}$ PRISCYLA D. MARCATO, ${ }^{c}$ NELSON DURÁN, \\ JUANITA FREER ${ }^{a, d}$ AND JAIME BAEZA ${ }^{a, d}$ \\ ${ }^{a}$ Centro de Biotecnología, Universidad de Concepción, Casilla 160-C, Chile. \\ ${ }^{b}$ Facultad de Ciencias Forestales, Universidad de Concepción, Casilla 160-C, Chile. \\ ${ }^{c}$ Laboratório de Química Biológica, Instituto de Química, Universidade Estadual de Campinas, CP 6154, Campinas, CEP 13083-970, SP, Brazil. \\ ${ }^{d}$ Facultad de Ciencias Quimicas, Universidad de Concepción, Casilla 160-C, Chile.
}

(Received: March 31, 2011 - Accepted: June 20, 2011)

\begin{abstract}
The production of bioethanol from pretreated lignocellulosic materials requires the utilization of microorganisms adapted to ferment the materials in conditions were high consistency, temperatures and inhibitors concentrations were commonly found. The yeast immobilization in calcium alginate capsules has been reported to enhance the yeast protection and increase the efficiency in the fermentation process. In this work, it was investigated the use Saccharomyces cerevisiae immobilized in calcium alginate and its performance in simultaneous saccharification and fermentation (SSF) of diluted-acid-pretreated Pinus radiata. Results showed that when immobilized yeast was used, the bioethanol yield from pretreated wood was higher than with free yeast cells during a SSF process. Maximum ethanol yield obtained from the acid pretreated and milled wood chips was $153 \mathrm{~L} /$ ton wood, while from the hydrolysate fraction it was $18 \mathrm{~L} /$ ton wood. The sum of ethanol produced from dilute acid pretreated $P$. radiata for both solid and liquid fractions was $171 \mathrm{~L}$ ethanol/ton wood from a maximum theoretical of $236 \mathrm{~L} /$ ton pretretated wood (or $72 \%$ of conversion).
\end{abstract}

Keywords: Pinus radiata, bioethanol, diluted acid pretreatment, immobilized yeast, simultaneous saccharification and fermentation.

\section{INTRODUCTION}

The rise of oil prices, the unavoidable fossil fuel shortage, the environmental impact caused by $\mathrm{CO}_{2}$ emissions, and the progressive expansion of the civilization have lead to an intense investigation for the development of alternative power sources, including the ethanol from renewable lignocellulosic biomass (LCB), such as wood or agriculture and forest residues. The LCB can be transformed by chemical or biological process aimed to cleave the physical and chemical bonds of vegetal fibers and components to produce energy as biofuels and biomaterials like bioethanol, bio-oil, methane, bioplastics, and others. ${ }^{1}$

The hydrolytic pretreatment with diluted mineral acids is one of the main processes used for the fractionation of wood biomass to improve the enzymatic digestibility and to solubilize sugars for its further fermentation. The main purposes of the pretreatment are lignin and hemicelluloses solubilization, reduction of cellulose crystallinity and increase the available surface area and pore volume of the substrate to allow a subsequent enzymatic hydrolysis with high production of fermentable sugars. ${ }^{2,3}$ For pretreated spruce wood (softwood) with sulfite pretreatment to overcome lignocelluloses recalcitrance (SPORL) at $180^{\circ} \mathrm{C}$ has been reported a enzymatic hydrolysis glucose yields of $372 \mathrm{~kg} /$ ton wood. ${ }^{4}$

The development of continuous processes for alcoholic fermentation to reduce costs and increase ethanol production led to the investigation of fermentation processes in which free cells, flocculants or immobilized yeast were used. The fermentation with free cells offers some advantages in comparison with the immobilized cells, as large contact area between cells and substrate, and the management of existing technology in the industrial processes. Among their disadvantages are the high cost of microbial recycling and installation, high contamination risks and susceptibility of the microorganism to environmental variations. ${ }^{5}$ The use synthetic or natural polymers to immobilize yeasts, as calcium alginate, carrageenin-oligochitosan, chitosan-carboxymethylcellulose, agarose, polyamide, among others, allows to protect the cells from inhibitors maintaining a high concentration of cells in the capsules, improving the thermal stability, maintaining a long time of operational stability of the encapsulated yeast and obtaining higher ethanol yields than in fermentations with the free yeast cells..$^{6,7}$

Saccharomyces cerevisiae is the yeast frequently used in the alcohol industry (wine, spirits and fuels) to ferment sugars from different kind of raw material such as grapes and other fruits, cereals, sugarcane, and lignocellulosic materials. The yeast is also used in researches of bio-elements bindings (e.g. cadmium, magnesium and calcium) in microorganisms due to the easiness of its cultivation and high biomass production in a relatively short time. ${ }^{8}$

For the conservation of yeast stocks or its immobilization for using in fermentation process it is necessary to maintain a high viability and genetic stability of the microorganism avoiding contaminations. Lyophilization (or freeze-drying) is a process that allows the conservation of yeast cells at room temperature $\left(18-20^{\circ} \mathrm{C}\right)$, however a decrease in yeast viability are observed and cryoprotector agents (sugars, albumin, milk, polyols, honey and amino acids) are used in order to avoid the cells damage in the freeze-drying process. ${ }^{9}, 10$ Entrapment of cells in alginate gel is popular because of the mild conditions used and the simplicity of the procedure to prepare the capsules and several reports are available employing this compound..$^{10-12}$ There are several studies on the composition of alginate and their suitability for cell immobilization..$^{13-17}$ Yamagiwa et al. ${ }^{18}$ tried the two-step preparation procedure by recoating the calcium alginate cell beads by plain alginate as a double layer to enhance the gel stability. ${ }^{19,20}$ Ruggeri et al. ${ }^{21}$ have attempted polyacrylamide coating over the alginate cell beads to enhance the structural stability. It was observed that Eudragit RL 100 (a copolymer of acrylic resin) coating of cell entrapped in alginate beads resulted in $15 \%$ higher diffusion of substrate and the leakage of cells was considerably reduced. Nagashima et al..$^{22}$ operated a pilot plant of 40,000 L capacity, using alginate-entrapped cells of yeast for alcohol fermentation for a period of $4000 \mathrm{~h}$ with a constant alcohol production rate of 8.5 to $9.0 \%$ by volume. Using Ca-alginate-entrapped cells of S. cereviceae, Iamuna and Ramakrishna ${ }^{23}$ reported rapid fermentation of high concentration sugar solution, thereby obtaining $20 \%$ (w/v) alcohol in $30 \mathrm{~h}$.

A high yield of ethanol has been reported to SSF process of hydrolyzed of corn stove alkaline pretreated and softwood with $\mathrm{SO}_{2}$ steam pretreated with $S$. cerevisiae immobilized in alginate..$^{24,25}$ Very recently, interesting results were discussed on SSF in a fluidized bed reactor (MSFBR) using glucose. Molasses gave comparative ethanol productivity in comparison to glucose in the MSFBR ${ }^{27}$ For $S$. cerevisiae has been found that free and immobilized cells achieve complete fermentation at the same time, and the growth rate of suspended cells is lower than immobilized cells when ethanol concentration are higher than $0.42 \mathrm{M}^{42}$ 
The aim of this study was to evaluate the use of lyophilized and calciumalginate-immobilized S. cerevisiae cells in the production of bioethanol by SSF of $P$. radiata wood chips pretreated by diluted sulfuric acid.

\section{EXPERIMENTAL}

\section{Yeast cultivation}

Saccharomyces cerevisiae (strain IR2-9) was from the culture collection of the Laboratory of Renewable Resources, Biotechnology Center, Universidad de Concepción, Chile. The yeast was previously selected and adapted to growth at temperatures of $40-42^{\circ} \mathrm{C}$ and was maintained in Petri dishes with solid medium composed by $50 \mathrm{~g} / \mathrm{L}$ glucose (Sigma Aldrich, Germany), $5 \mathrm{~g} / \mathrm{L}$ yeast extract powder (Himedia RM 027, India), $5 \mathrm{~g} / \mathrm{L}$ soy peptone (Becton Dickinson and Company, USA), $1 \mathrm{~g} / \mathrm{L} \mathrm{KH}_{2} \mathrm{PO}_{4}$ (Sigma-Aldrich, Germany), 0.5 $\mathrm{g} / \mathrm{L} \mathrm{MgSO} .7 \mathrm{H}_{2} \mathrm{O}$ (Fluka Chemika, Switzerland), $1 \mathrm{~g} / \mathrm{L} \mathrm{NH} \mathrm{Cl}$ (Sigma-Aldrich, Germany) and $20 \mathrm{~g} / \mathrm{L}$ agar (Merck KGaA, Germany). ${ }^{27}$ All culture media used in this study were autoclaved at $121^{\circ} \mathrm{C}$ for $20 \mathrm{~min}$. Five colonies from stock cultures were used to inoculate of $10 \mathrm{~mL}$ of liquid medium and incubated in a shaker for $24 \mathrm{~h}$ at $40^{\circ} \mathrm{C}$ and $150 \mathrm{rpm}$. The precultured cells $(10 \mathrm{~mL})$ were used to inoculate $50 \mathrm{~mL}$ of culture medium and incubated at $24,48,72$ and $96 \mathrm{~h}$, in order to evaluate the biomass production in different periods of cultivation. After each incubation period, the samples were centrifuged at $3500 \mathrm{rpm}$ for 15 min. The supernatant was eliminated and the biomass was washed twice with $50 \mathrm{~mL}$ of $0.9 \% \mathrm{NaCl}$ solution. The yeast biomass was transferred to a $250 \mathrm{~mL}$ round bottom flask, frozen for $12 \mathrm{~h}$ and lyophilized until complete elimination of water (approximately $18 \mathrm{~h}$ ). The lyophilized yeast was stored in centrifuge plastic tubes at room temperature until further use.

\section{Yeast cultivation in $\mathrm{CaCl}_{2}$ supplemented medium}

A buffered liquid medium of sodium citrate $0.05 \mathrm{M}, \mathrm{pH} 4.8$ was prepared contained $50 \mathrm{~g} / \mathrm{L}$ glucose, $5 \mathrm{~g} / \mathrm{L}$ yeast extract, $5 \mathrm{~g} / \mathrm{L}$ soy peptone, $1 \mathrm{~g} / \mathrm{L} \mathrm{KH}_{2} \mathrm{PO}_{4}$, $0.5 \mathrm{~g} / \mathrm{L} \mathrm{MgSO}_{4} .7 \mathrm{H}_{2} \mathrm{O}, 1 \mathrm{~g} / \mathrm{L} \mathrm{NH} \mathrm{N}_{4} \mathrm{Cl}$. The culture medium was supplemented with $\mathrm{CaCl}_{2} \cdot \mathrm{H}_{2} \mathrm{O}$ (Sigma-Aldrich, Germany) at the concentrations of 3.5 , 5.8 and $8.0 \%(\mathrm{w} / \mathrm{v})$, equivalent to $1.3,2.1$ and $2.9 \%$ of $\mathrm{Ca}^{2+}$. In a $125 \mathrm{~mL}$ Erlenmeyer flask, $10 \mathrm{~mL}$ of culture medium supplemented with $\mathrm{CaCl}_{2}$ and 40 $\mathrm{mg}$ of lyophilized yeast precultured for $24,48,72$ or $96 \mathrm{~h}$ were added. The flasks were sealed and incubated at $40^{\circ} \mathrm{C}, 150 \mathrm{rpm}$ for $24 \mathrm{~h}$. Aliquots of $1 \mathrm{~mL}$ of culture medium were taken at the end of the assays for viable cells count. The test was performed to see if the time of preculture of yeast and exposure to a concentration of $\mathrm{CaCl}_{2}$ similar to those used to form the capsules have an influence on the viability of yeast cells.

\section{Yeast immobilization}

Yeast immobilization was carried out as follow: sodium alginate (3\%) was prepared by dissolving $1.5 \mathrm{~g}$ of sodium alginate (Sigma-Aldrich, Germany) in $50 \mathrm{~mL}$ of water under stirring. Calcium solutions were prepared by dissolving $3.5 \mathrm{~g}$ and $8.0 \mathrm{~g}$ of $\mathrm{CaCl}_{2} \cdot \mathrm{H}_{2} \mathrm{O}$ in $100 \mathrm{~mL}$ of distilled water. Six hundred $\mathrm{mg}$ of lyophilized yeast were added to $20 \mathrm{~mL}$ of alginate solution in a $100 \mathrm{~mL}$ beaker. The yeast solution was pumped through a peristaltic pump $(2 \mathrm{~mL} / \mathrm{min})$ to the calcium solutions ( $3.5 \mathrm{~g}$ or $8.0 \mathrm{~g} / 100 \mathrm{~mL}$ ) under stirring. The alginate capsules formed were stored in $40 \mathrm{~mL}$ calcium solution inside a $100 \mathrm{~mL}$ plastic flask with screw cap and maintained at $4^{\circ} \mathrm{C}$ until use. The amount of encapsulated viable cells in each particle was determined by dissolving two particles in 10 $\mathrm{mL}$ sodium citrate $0.1 \mathrm{M}$ at $\mathrm{pH} 4.8$ followed by serial dilutions, plating and counting the viable yeast colonies. To count total and viable yeast cells, the methods of serial dilution and hemocytometry were used. The count of viable cells by means of plating in Petri dishes with solid medium was carried out by the following procedure: $1 \mathrm{~mL}$ of sample was added $9 \mathrm{~mL}$ of nanopure water in a test tube. The solution was homogenized and successive dilutions were done by using $1 \mathrm{~mL}$ of the initial solution and adding to $9 \mathrm{~mL}$ of nanopure water. A $0.1 \mathrm{~mL}$ aliquot of the microorganisms sample was added into the Petri dish containing solid culture medium and spread out with a glass rod bent. Colonies count was carried out after $24 \mathrm{~h}$ of growth at $40^{\circ} \mathrm{C}$. The count of total cells was carried out by distributing a volume of $0.1 \mathrm{~mL}$ in a Neubauer chamber and the number of cells present in the sample was counted. The readings were done in triplicate for each sample.

\section{Pretreatment of $\boldsymbol{P}$. radiata wood chips with diluted sulfuric acid}

P. radiata D. Don wood chips (average size of $2.5 \times 2.0 \times 0.7 \mathrm{~cm}$ ) were provided by a local pulp mill. Acid pretreatment was carried out in a 3.78 L Parr reactor with diluted sulfuric acid according to a factorial design with star points conformed by 17 experiments. The star point were distributed to a distance of 1 from the central point and the values of the temperature, time and
$\mathrm{pH}$ variables were codified as -1 (low value), +1 (high value) and 0 (central point). The variable influence was determined by means of surface response methodology and the statistical validation made by ANOVA test with $95 \%$ of confidence interval. Pretreatment conditions were the following: $50 \mathrm{~g}$ of wood chips (dry basis), liquor/wood ratio: $4 / 1(\mathrm{v} / \mathrm{w})$, temperature of $120^{\circ} \mathrm{C}$ (level -1) and $170^{\circ} \mathrm{C}($ level +1$)$, pretreatment time of $1 \mathrm{~min}($ level -1$)$ and $60 \mathrm{~min}$ (level $+1)$, liquor $\mathrm{pH}$ of $1.0($ level -1$)$ and $2.5($ level +1$)$. The design correspond to a central composite circumscribed cuboidal (CCC). A CCC design provide high quality predictions over the entire design spaces, but require factor settings outside the range of the factors in the factorial part. , $^{36,37}$

Previously to the pretreatment, wood chips were weighed and placed in a $500 \mathrm{~mL}$ beaker with $200 \mathrm{~mL}$ of nanopure water for $24 \mathrm{~h}$. Afterwards, the water was drained and the wood chips were weighed to determine the absorbed amount of water and to determined the amount of acid solution that should be added to achieve the desired $\mathrm{pH}$ for the pretreatment. After reaction, the reactor was cooled, opened and the liquor was filtered. Solids were immersed in $200 \mathrm{~mL}$ of distilled water for $60 \mathrm{~min}$ and later filtered. Liquid fractions were combined, made to $500 \mathrm{~mL}$ with distilled water and chemical characterized by HPLC in a Merck Hitachi instrument with an Aminex HPX-87H column

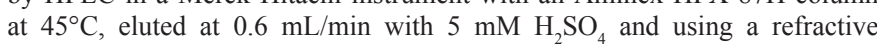
index detector. The pretreated chips were weighed and a portion was used to determine dry matter content in an oven at $105^{\circ} \mathrm{C}$ overnight. The result was used to determine the yield of solids after pretreatment. A fraction of the pretreated wood chips ( $70 \%$ dry weight) was milled in a knife mill. The ground material obtained was not washed and was stored in plastic bottles until use. A fraction of the pretreated wood chips was characterized for carbohydrates and lignin content by acid hydrolysis with $72 \%$ sulfuric acid following the methodology published elsewhere. ${ }^{29}$

Fermentation of acid pretreated $P$. radiat $a$ using immobilized yeast

The efficiency of the immobilized yeast in the fermentation was first evaluated in a synthetic medium composed by $50 \mathrm{~g} / \mathrm{L}$ glucose, $5 \mathrm{~g} / \mathrm{L}$ yeast extract, $5 \mathrm{~g} / \mathrm{L}$ soy peptone, $1 \mathrm{~g} / \mathrm{L} \mathrm{KH}_{2} \mathrm{PO}_{4}, 0.5 \mathrm{~g} / \mathrm{L} \mathrm{MgSO}{ }_{4} \cdot 7 \mathrm{H}_{2} \mathrm{O}, 1 \mathrm{~g} / \mathrm{L}$

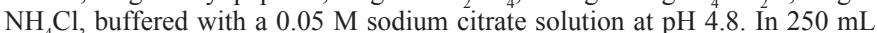
Erlenmeyer flask, $30 \mathrm{~mL}$ of medium and $300 \mathrm{mg}$ of encapsulated yeast were added. The flask was sealed and fermentation was carried out in a shaker at $40^{\circ} \mathrm{C}, 150 \mathrm{rpm}$ for $72 \mathrm{~h}$.

Pretreated $P$. radiata was bioconverted to bioethanol by simultaneous saccharification and fermentation process using cellulase enzymes and immobilized yeast. Approximately $3 \mathrm{~g}$ (dry basis) of milled (40/60 mesh) solid residue was weighed and placed in an Erlenmeyer flask with $30 \mathrm{~mL}$ of the buffered medium (supplemented with salts but without additional glucose source). To this suspension, an enzyme load of 20 FPU Celluclast (80 FPU/ $\mathrm{mL}$ ) and 40 IU Novozymes b- glucosidase (234 IU) per gram of dry material was added. The immobilized yeast added to fermentation medium was equivalent to $100 \mathrm{mg}$ of yeast $/ \mathrm{g}$ of solid material and the number of viable cells was approximately $1 \times 10^{7}$. Ethanol produced was measured at $6,24,48$ and $72 \mathrm{~h}$ of fermentation by gas chromatography in a Perkin Elmer autosystem XL-Head space, with FID detector and a HPS MS 30 m column. A maximum production of $0.51 \mathrm{~g}$ ethanol/g glucose was assumed for the calculation of theoretical ethanol production, considering that all the glucose available in pretreated material was available for fermentation.

Liquid fraction from acid pretreatment (hemicellulose-enriched liquor) was also fermented. A $30 \mathrm{~mL}$ aliquot was adjusted to $\mathrm{pH} 4.5$ with $4 \mathrm{M} \mathrm{KOH}$ solution and buffered with $0.05 \mathrm{M}$ sodium citrate at $\mathrm{pH} 4.8$. The hydrolysate was supplemented with an enzyme load of 10 FPU Celluclast and 10 IU of Novozymes b-glucosidase. The fermentation conditions, sampling and analyses were done as previously described. All assays reported in this section were performed in triplicate.

\section{Electron microscopy of encapsulated yeast}

The morphology of the yeast alginates capsules were studied using Scanning Electron Microscopy (SEM). SEM (Jeol - JSM-6360LV) was performed at a voltage of $20 \mathrm{kV}$ and the samples were previously coated with gold/palladium under vacuum by sputtering using a BAL-TEC's apparatus. Secondary electron images were obtained. This method allowed the visualization of possible changes in the macrocapsule after the fermentation process. ${ }^{34,42}$ 


\section{RESULTS AND DISCUSSION}

\section{Immobilization of $\boldsymbol{S}$. cerevisiae in calcium alginate}

Saccharomyces cerevisiae yeast cultivated from 24 to 96 h showed 2.8-7.8 $\mathrm{x} 10^{10}$ total cells $/ \mathrm{mL}$ from which $1.5-3.8 \times 10^{8}$ were determined as viable cells. After freeze-drying viable cells number dropped to an average value of $4.0 \mathrm{x}$ $10^{6}$ cells $/ \mathrm{mL}$. As it is well known, lyophilization is a process widely used to preserve foods and microorganisms, however, the cooling rate and the use of protective agents are some critical factors involving in the process that affect the viability and stability of the microorganisms. ${ }^{8,9}$ Results showed that cultivating the yeast for a $24-48 \mathrm{~h}$ period provided enough amounts of viable cells for further immobilization process and for the formation of capsules with more uniform diameter than when free cells without freeze-drying were used. For the optimization of $S$. cerevisiae culture in alginate-chitosan-alginate microcapsule and glucose fermentation, it was reported that an initial cell density of $3 \times 10^{6}$ cells $/ \mathrm{mL}$ was an adecuated amount for proliferation, metabolism and ethanol production. ${ }^{34}$

When the determination of viable cells was done with the encapsulated yeast, it was observed that the yeast encapsulated in calcium alginate produced lower number of colonies than free yeasts that were grown without contact with calcium solution. Therefore, it was necessary to determine if the use of certain concentration $\mathrm{CaCl}_{2}$ solution for formation of the alginate capsules could have some negative effect in further yeast growth and in the number of viable cells after encapsulation. To evaluate this, some assays were performed in liquid medium supplemented with calcium and using the freeze-drying yeast obtained after $24 \mathrm{~h}$ to $96 \mathrm{~h}$ of precultivation. The time of incubation was 24 $\mathrm{h}$, after which viable cells were counting (Table 1). It was observed that at low concentrations of $\mathrm{CaCl}_{2} \cdot 2 \mathrm{H}_{2} \mathrm{O}$ in culture medium $(3.5 \%)$, the yeast culture for $24 \mathrm{~h}$ have a similar number of viable cells as the yeasts cultured for 48 , 72 and 96 h. At high concentrations of $\mathrm{CaCl}_{2} \cdot 2 \mathrm{H}_{2} \mathrm{O}(5.8$ and $8.0 \%$ ), viable cells decreased notoriously, indicating that high amount of calcium could inhibit yeast growth, however there is no indication if it could affect ethanol production during fermentation process. It was reported that $70 \%$ of $\mathrm{Ca}^{2+}$ released from the capsules can be found in the fermentation medium at $24 \mathrm{~h}$ of fermentation. An initial cell population of $S$. cerevisiae over $10^{5}$ is considered adequate for immobilization in calcium alginate. ${ }^{43}$

Table 1. Viable cells of $S$. cerevisiae after $24 \mathrm{~h}$ of growth in culture medium supplemented with calcium chloride

\begin{tabular}{|c|c|c|c|c|}
\hline & & Viable cells & \\
\hline $\mathrm{CaCl}_{2} .2 \mathrm{H}_{2} \mathrm{O}$ & $\begin{array}{c}\text { Yeast precultured } \\
\text { for } 24 \mathrm{~h}\end{array}$ & $\begin{array}{c}\text { Yeast precultured for } \\
48 \mathrm{~h}\end{array}$ & $\begin{array}{c}\text { Yeast precultured for } \\
72 \mathrm{~h}\end{array}$ & $\begin{array}{c}\text { Yeast precultured for } \\
96 \mathrm{~h}\end{array}$ \\
\hline $3.5 \%$ & $6.910^{10}$ & $4.8 \times 10^{10}$ & $3.5 \times 10^{10}$ & $1.8 \times 10^{10}$ \\
\hline $5.8 \%$ & $2.0 \times 10^{8}$ & $2.9 \times 10^{6}$ & $1.3 \times 10^{6}$ & $9.1 \times 10^{9}$ \\
\hline $8.0 \%$ & $7.5 \times 10^{5}$ & $9.0 \times 10^{5}$ & $8.5 \times 10^{6}$ & $1.4 \times 10^{7}$ \\
\hline
\end{tabular}

Dilute acid pretreatment and SSF of $P$. radiata using immobilized $S$. cerevisiae

Chemical composition of $P$. radiata used in the study was $44.1 \pm 0.7 \%$ glucans, $21.4 \pm 0.9 \%$ hemicelluloses, $29.1 \pm 0.1 \%$ lignin and $2.8 \pm 0.1 \%$ ethanol/toluene soluble extractives, the chemical composition is similar to that previously reported for the species. ${ }^{46}$ Dilute acid pretreatment of $P$. radiata wood chips was performed following an experimental design were the response of the evaluated parameters (temperature, time and $\mathrm{pH}$ ) was the glucose concentration in the recovered pretreated material (solid fraction). Results were evaluated by means of a response surface methodology. Table 2 shows the results obtained for the 17 experiments generated by the experimental design.

Table 2. Composition of water insoluble residue and hydrolysate after dilute acid pretreatment of $P$. radiata wood chips.

\begin{tabular}{|c|c|c|c|c|c|c|c|c|c|c|c|}
\hline \multirow[b]{2}{*}{$\begin{array}{l}\text { Sam- } \\
\text { ple }\end{array}$} & \multirow[b]{2}{*}{$\begin{array}{l}\text { Tem- } \\
\text { perature } \\
\left({ }^{\circ} \mathrm{C}\right)\end{array}$} & \multirow[b]{2}{*}{$\mathrm{pH}$} & \multirow[b]{2}{*}{$\begin{array}{l}\text { Time } \\
(\min )\end{array}$} & \multicolumn{4}{|c|}{ Composition of solid fraction $(\mathrm{kg} /$ ton wood) } & \multicolumn{3}{|c|}{$\begin{array}{c}\text { Composition of liquid fraction }(\mathrm{kg} / \text { ton } \\
\text { wood) }\end{array}$} & \multirow[b]{2}{*}{$\begin{array}{l}\text { Formic } \\
\text { acid }\end{array}$} \\
\hline & & & & $\begin{array}{l}\text { Yield } \\
\text { of } \\
\text { solids }\end{array}$ & $\begin{array}{l}\text { Lig- } \\
\text { nin }\end{array}$ & $\begin{array}{l}\text { Glu- } \\
\text { cans }\end{array}$ & $\begin{array}{l}\text { Hemi- } \\
\text { cellu- } \\
\text { loses }\end{array}$ & $\begin{array}{l}\text { Glu- } \\
\text { cans }\end{array}$ & $\begin{array}{l}\text { Hemice- } \\
\text { lulloses }\end{array}$ & Acetic acid & \\
\hline 1 & 120 & 1 & 0 & 86.7 & 28.3 & 37.9 & 12.6 & 2.0 & 18.0 & 2.0 & 0.0 \\
\hline 2 & 145 & 1.75 & 30 & 84.4 & 27.6 & 37.9 & 11.7 & 2.0 & 20.0 & 1.0 & 1.0 \\
\hline 3 & 145 & 1.75 & 30 & 81.2 & 26.7 & 35.2 & 8.19 & 3.0 & 29.0 & 2.0 & 2.0 \\
\hline 4 & 145 & 1.75 & 30 & 81.5 & 26.7 & 36.9 & 8.9 & 2.0 & 29.0 & 2.0 & 2.0 \\
\hline 5 & 120 & 2.5 & 0 & 92.6 & 24.4 & 37.8 & 18.6 & 0.0 & 8.0 & 0.0 & 0.0 \\
\hline 6 & 170 & 1.75 & 30 & 71.6 & 26.1 & 37.4 & 2.4 & 11.0 & 74.0 & 6.0 & 4.0 \\
\hline 7 & 145 & 1 & 30 & 69.1 & 26.8 & 36.6 & 1.3 & 16.1 & 60.0 & 6.0 & 5.0 \\
\hline 8 & 170 & 1 & 60 & 68.9 & 24.4 & 31.4 & 0.0 & 10.0 & 6.0 & 0.0 & 0.0 \\
\hline 9 & 170 & 2.5 & 60 & 76.5 & 27.2 & 34.6 & 4.8 & 13.0 & 30.0 & 0.0 & 0.0 \\
\hline 10 & 170 & 2.5 & 0 & 63.6 & 21.8 & 29.7 & 7.1 & 4.0 & 11.0 & 1.0 & 1.0 \\
\hline 11 & 145 & 1,75 & 60 & 84.9 & 27.8 & 38.5 & 8.8 & 0.0 & 0.0 & 3.0 & 3.0 \\
\hline 12 & 145 & 2,5 & 30 & 86.4 & 26.6 & 36.0 & 12.8 & 0.0 & 0.0 & 0.0 & 0.0 \\
\hline 13 & 120 & 2.5 & 60 & 89.2 & 25.7 & 33.6 & 15.7 & 0.0 & 0.0 & 0.0 & 0.0 \\
\hline 14 & 120 & 1.75 & 30 & 89.1 & 27.5 & 38.4 & 13.3 & 0.0 & 6.0 & 1.0 & 1.0 \\
\hline 15 & 120 & 1 & 60 & 86.5 & 26.5 & 38.2 & 9.8 & 15.0 & 100.0 & 10.0 & 4.0 \\
\hline 16 & 145 & 1.75 & 0 & 88.3 & 27.4 & 12.4 & 5.9 & 0.0 & 9.0 & 1.0 & 0.0 \\
\hline 17 & 170 & 1 & 0 & 68.1 & 26.3 & 32.1 & 0.0 & 32.0 & 46.0 & 11.0 & 11.0 \\
\hline
\end{tabular}


Equation 1 showed a linear relationship for the glucan yield in the pretreated material that was validated by ANOVA test at $95 \%$ of confidence level, where $Y$ is the glucan yield (\%) in the solid residue after acid pretreatment, $T$ is the reaction temperature $\left({ }^{\circ} \mathrm{C}\right)$ and $t$ is the residence time in the reactor (min).

$$
\mathrm{Y}(\%)=36.05 \pm 0.34-2.79 \pm 0.46 \mathrm{~T}+1.37 \pm 0.45 \mathrm{t}
$$

The values of the ANOVA test that gave statistical validity to the model were: $\mathrm{R}^{2}=0.82, \mathrm{Q}^{2}=0.66$, model validation 0.87 and reproducibility of the model 0.77 . A $\mathrm{R}^{2}$ (multiple correlation coefficient) value higher than 0.75 indicates aptness of the model..$^{39}$ The model F-value is 20.12 and lack of fit F-value is 1.14. High F-value and non-significant lack of fit indicate the model has a good fit. The model can explain $82 \%$ variation in the response. The negative coefficient for the temperature indicates that high temperature increase cellulose solubilization, decreasing glucose content in the water insoluble residue. Statistical analysis showed that the $\mathrm{pH}$ of the acid solution used ( $\mathrm{pH} 1$ to 2.5 ) was not a variable that influenced directly in the process according to the statistical model. This result is similar to that reported for modeling and optimization of the dilute-sulfuric-acid pretreatment of poplar in which the temperature and not the acid concentration is the major factor affecting the extent of sugar recovery from pretreatment. Only at high temperature $\left(180^{\circ} \mathrm{C}\right)$ is when increasing the acid concentration has some effect on the sugar recovery. ${ }^{44}$

The glucan amount retained in solid fraction varied from 12 to $38 \mathrm{~kg}$ / ton wood, which represent from $30 \%$ to $90 \%$ of the glucose present in the wood biomass. The yield of solids after pretreatment was between $63-89 \mathrm{~kg} /$ ton wood. Lignin content in pretreated wood chips was between $21-28 \mathrm{~kg}$ ton wood (Table 2). These results were similar to those obtained for milled spruce (a softwood) pretreated by steam explosion using $3 \% \mathrm{SO}_{2}, 190^{\circ} \mathrm{C}$ and 2 min of reaction time in which the recovery of glucose in the water-insoluble solids was $86.6 \mathrm{~kg} /$ ton wood. ${ }^{41}$ Liquid fractions were composed mainly by hemicellulose sugars, which was consistent with the fact that acid prehydrolysis in temperatures between $120-170^{\circ} \mathrm{C}$ is able to hydrolyze mainly hemicelluloses with low lignin and cellulose solubilization. ${ }^{30}$

Precultured immobilized yeast for $24 \mathrm{~h}$ and immobilized in calcium alginate, using calcium chloride solutions $3.5 \%$ and $8.0 \%(\mathrm{w} / \mathrm{v})$ and sodium alginate $3 \%(\mathrm{w} / \mathrm{v})$, were first evaluated in the fermentation of synthetic medium containing $50 \mathrm{~g} / \mathrm{L}$ of glucose. Maximum ethanol yield was $64 \%$ and $74 \%$ from the theoretical for yeast immobilized in $3.5 \%$ and $8.0 \%$ calcium alginate, respectively (Figure 1).

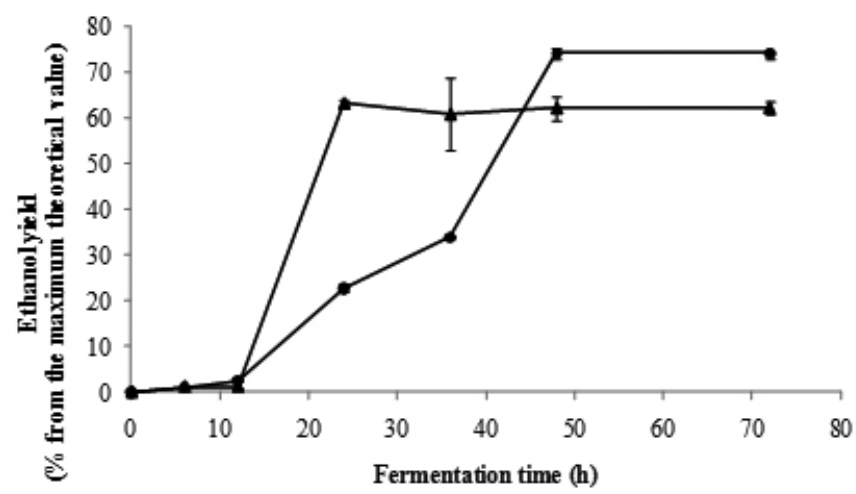

Figure 1. Ethanol yield obtained from synthetic medium fermented by yeast precultured for $24 \mathrm{~h}$ and immobilized in $3.5 \%$ (black filled triangle) and $8 \%$ (black filled circle) calcium alginate.

No residual glucose was found in the medium at end of the fermentation process indicating that besides its bioconversion in ethanol it was also used for cell growth and maintenance. The lag phase was observed for the SSF with yeast immobilized in $3.5 \%$ calcium alginate after $24 \mathrm{~h}$ fermentation. In the case of yeast encapsulated in calcium alginate $8.0 \%$ was observed a low ethanol production at the beginning of the fermentation, but after 36 hours the ethanol yield was higher than for yeast encapsulated in $3.5 \%$ calcium alginate. This difference in ethanol yield can be explained by differences in the permeability of the matrix immobilization with different concentrations of calcium, implying a different behavior in the adsorption of glucose and excretion of ethanol. The diffusion resistance of immobilized cells structures may be beneficial to microorganism growth and activity by limiting the local concentration of an inhibiting substrate/ product. $^{35}$

Considering that immobilized yeasts were suitable for use in fermentation, the sample number 6 of the experimental design of prehydrolyzed $P$. radiata wood chips (milled and unwashed) containing $37 \mathrm{~kg}$ glucan/ton wood, $26 \mathrm{~kg}$ lignin/ton wood and $2 \mathrm{~kg}$ hemicelluloses/ton wood (on wood basis) was used for bioethanol production by SSF using immobilized yeasts. Consistency used was $10 \%$ ( $3 \mathrm{~g}$ of milled pretreated wood in $30 \mathrm{~mL}$ of medium). The maximum ethanol amount possible to obtain from this sample considering completing conversion of glucose in ethanol with a yield of $51 \%$ is $236 \mathrm{~L}$ ethanol/ton pretreated wood. For untreated $P$. radiata the maximum ethanol amount to be obtained is $316 \mathrm{~L} /$ ton wood from the amount of glucose present in the wood. The pretreated wood was fermented in medium supplemented with cellulases and with immobilized yeast in a SSF process. When pretreated milled wood was submitted to SSF with free yeast cells a fermentation efficiency of $22 \%$ from the theoretical was obtained $(52 \mathrm{~L}$ ethanol/ton pretreated wood). On the other hand, when fermentation was carried out with calcium-alginate immobilized yeast (precultured for $24 \mathrm{~h}$, freeze-dried and immobilized in 3.5\% or $8 \%$ calcium alginate) the fermentation efficiency was significantly increased (Figure 2). Results showed that fermentation performance of immobilized yeast in $3.5 \%$ calcium alginate was slightly superior as compared with free cell and a fermentation efficiency of $29 \%$ of ethanol was obtained after $48 \mathrm{~h}$ of SSF. When SSF of prehydrolyzed and milled $P$. radiata wood chips was carried out with yeast immobilized in $8 \%$ calcium alginate the fermentation efficiency was significantly increased reaching a $65 \%(153 \mathrm{~L} /$ ton pretreated wood $)$ from the maximum theoretical value.

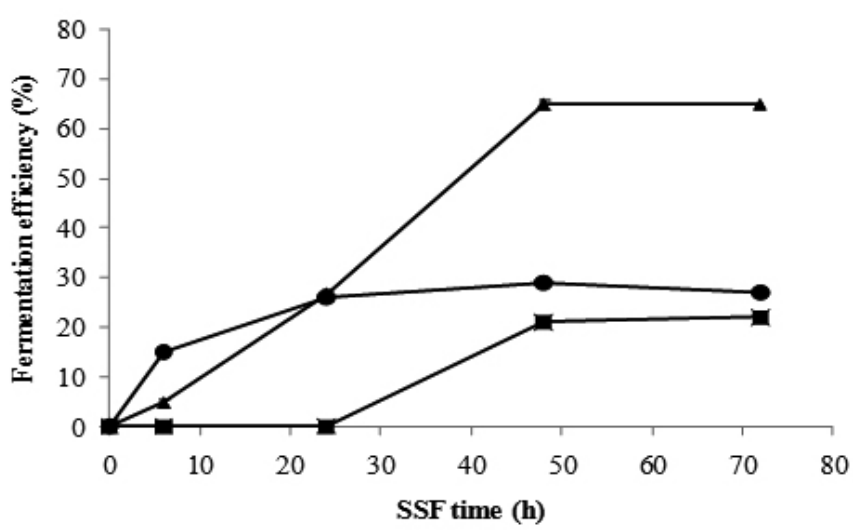

Figure 2. Fermentation efficiency obtained from dilute acid pretreated $P$. radiata using free yeast (black filled square), yeast precultured for $24 \mathrm{~h}$ and immobilized in $3.5 \%$ (black filled circle) or $8 \%$ (black filled triangle) calcium alginate.

The difference in the fermentation results when capsules formed with $8 \%$ $\mathrm{CaCl}_{2}$ are compared with the capsules formed with $3.5 \% \mathrm{CaCl}_{2}$ can be explained by possible differences in the diffusion characteristics of the membrane of the capsule that can be offered more protection for yeast immobilized to the presence of exogenous ethanol produced in the fermentation and inhibitors from lignin. The result obtained could be compared to the one where Picea abies (a softwood) was pretreated in two steps with diluted acid $\left(180-200^{\circ} \mathrm{C}\right.$ for 2-10 min with $0.5-2 \% \mathrm{H}_{2} \mathrm{SO}_{4}$ ) followed by SSF at $2 \%$ substrate consistency and ethanol yield of $65 \% .{ }^{40}$ For lodgepole pine wood pretreated with sulfite pretreatment to overcome recalcitrance of lignocelluloses (SPORL) has been reported maximum ethanol yield of $270 \mathrm{~L} /$ ton. SPORL pretreatment differs from a dilute acid pretreatment by the addition of sulfite that introduce sulfonic groups at the lignin which can be depolimerize and dissolve the lignin, allowing a higher conversion of sugars in the enzymatic hydrolysis compared with dilute acid pretreatment. ${ }^{45}$

The acid hydrolysate (hemicellulose-enriched fraction) from the same pretreated material used in the previous SSF assay was also fermented with immobilized yeast to evaluate the suitability of glucan and C6-hemicelluloses 
dissolved being fermented to ethanol. The amount of C6 sugars in this hydrolysate was approximately $80 \mathrm{~kg} /$ ton wood, which could generate $50 \mathrm{~L}$ ethanol/ton wood. Fermenting the liquid fraction with immobilized yeast produced a maximum conversion of sugars in ethanol of $36 \%$ or $18 \mathrm{~L}$ ethanol/ton wood. Acetic acid was present at a concentration of $0.6 \%(0.6 \mathrm{~g}$ acetic acid/100 g dry wood) and formic acid concentration of $0.4 \%$. These concentrations of fermentation inhibitors are low in comparison with those reported for the fermentation of liquid fraction of sulfuric acid pretreated $P$. abies, with concentrations of acetic acid, furfural and 5-hydroxy methylfurfural of: $1.6,0.3$ and $0.6 \mathrm{~g} / 100 \mathrm{~g}$ dry raw material, respectively. Under these concentrations of the inhibitors the yield after fermentation of the liquid fraction from pretreatment was $94 \%$ of the theoretical ethanol yield, indicating that no inhibition occurred. ${ }^{40}$

The sum of ethanol produced from dilute acid pretreated $P$. radiata for both solid and liquid fraction was $171 \mathrm{~L}$ ethanol/ton wood. Ethanol production from wood pretreated by auto-hydrolysis or with $1 \%$ sulfuric acid followed by enzymatic hydrolysis and fermentation was reported in the range of 202$240 \mathrm{~L} /$ ton of wood. ${ }^{31,33}$ Ethanol produced from loblolly pine appeared with competitive value with ethanol produced from corn or other lignocellulosic biomass (258-388 L/ton of wood). ${ }^{34}$ For $P$. abies pretreated by steam explosion with $\mathrm{SO}_{2}$ at $215^{\circ} \mathrm{C}$ for $5 \mathrm{~min}$ and SSF with Novozym 188 beta-glucosidase 28 $\mathrm{IU} / \mathrm{g}$ cellulose and Celluclast of $32 \mathrm{FPU} / \mathrm{g}$ cellulose and using $5 \%$ of substrate consistency a maximum ethanol yield $68 \%$ of the theoretical based was reported. ${ }^{41}$

Our results showed that immobilized yeast has a potential to be used in the fermentation of acid pretreated lignocellulosic materials, however, some variables in the process (severity of pretreatment, enzymes and yeast loads, solid/liquid ratio in SSF, among others) should be optimized to increase ethanol yield for both technical and economical viability of the process. Moreover, in preliminary experiments fermentation of synthetic medium containing a glucose concentration of $50 \mathrm{~g} / \mathrm{L}$ was observed that yeast immobilized in calcium alginate can be reused up to 3 times, maintaining an ethanol yield of approximately $70 \%$ after $72 \mathrm{~h}$ of fermentation $(69 \%, 70 \%$ and $72 \%$ of ethanol yield in each experiment, respectively). This represents an advantage of the process that allows lower costs compared with processes in which free cells are used.

\section{Scanning electron microscopy analysis (SEM)}

The morphology of the capsules with the immobilized yeast was analyzed by SEM. The yeast encapsulation changes the particles surface increasing their roughness as shown in Figure 3. Furthermore, the yeast encapsulation increased the particles size from $1540 \mathrm{~mm}$ to $1970 \mathrm{~mm}$ indicating the $S$. cerevisiae encapsulation.
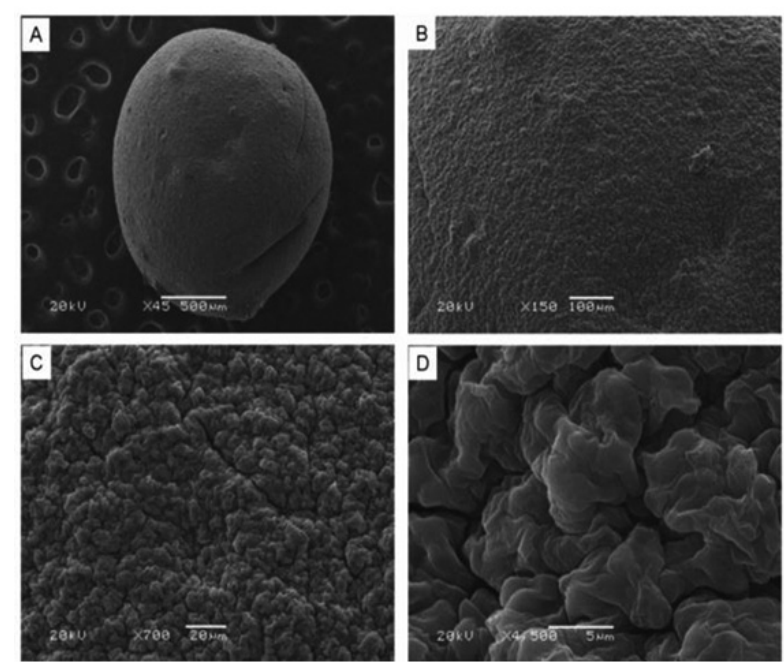

Figure 3. SEM micrographs of alginate particles before fermentation process: A) $\mathrm{x} 45$, B) $\mathrm{x} 150$, C) $\mathrm{x} 700$, D) $\mathrm{x} 4500$. Scanning electron microscopy $\mathrm{A}$ and $\mathrm{B}$ showed the smooth surface of the calcium alginate capsules without yeast. SEM C and D showed a rough surface of the capsule with immobilized S. cerevisiae.
After the fermentation process, the particles with yeast were also analyzed by SEM. This process changes the particles surface, but did not change the particle size (approximately $1567 \mathrm{~mm}$ ) as shown in Figure 4 . Small cavities (40 $\mathrm{mm}$ of diameter) appeared in the surface of the capsules probably due to the ethanol and $\mathrm{CO}_{2}$ production and their permeation to outside the particles wall.
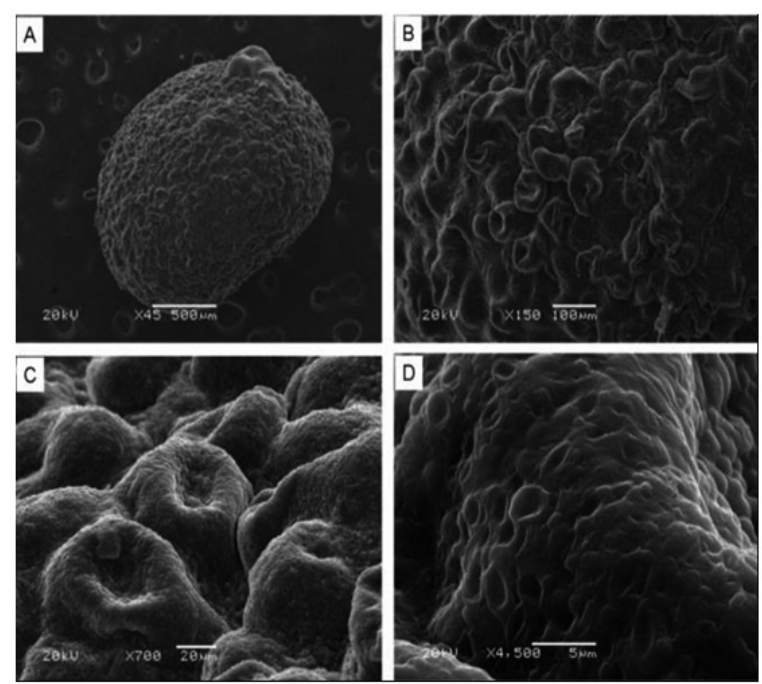

Figure 4. SEM micrographs of alginate particles with yeast after fermentation process: A) $x 45$, B) $x 150$, C) $\times 700$, D) $\times 4500$. Scanning electron microscopy A-D showed an increase in the porosity of the capsules with immobilized yeast after fermentation.

\section{CONCLUSIONS}

The use of immobilized Saccharomyces cerevisiae IR2-9 strain in calcium alginate, showed good production of ethanol for a synthetic fermentation medium (glucose), liquid and solid fraction of dilute acid pretreatment of wood chips $P$. radiata. The best ethanol yields were obtained with yeast encapsulated in $8.0 \%$ calcium chloride and 3\% alginate. After fermentation, the capsules do not show variation in size, which indicates a low rate of growth of immobilized yeast. The encapsulated cells can be used up to 3 times for fermentations with yields of $70 \%$ from the theoretical maximum value. Ethanol yield for liquid and solid fraction of the dilute acid pretreatment was $65 \%$ of the theoretical considering only the conversion of the glucans present in P. radiata wood chips which can be considered high for an one-step dilute acid pretreatment.

\section{ACKNOWLEDGEMENTS}

Financial support from Fondo Nacional de Desarrollo Científico y Tecnológico (FONDECYT, grant number 1070492) and CNPq/FAPESP (Brazil) is acknowledged. H. Franco thanks the National Research Program 2005-2010 of SENACYT-IFARHU, Panama for a PhD. grant.

\section{REFERENCES}

1. N. Mosier, C. Wyman, B. Dale, R. Elander, Y.Y. Lee, M. Holtzapple, M. Ladisch, Bioresour. Technol. 96, 673 (2005).

2. Y. Sun, J. Cheng, Bioresour. Technol. 83, 1 (2002).

3. A. Esteghlalian, A.G. Hashimoto, J.J. Fenske, M.H. Penner, Bioresour Technol. 59, 129 (1996).

4. J.Y. Zhu, X.J. Pan, Bioresour. Technol. 101, 4292 (2010)

5. J.N. Vasconcelos, C.E. Lopes, CE, F.P. França, Braz. J. Chem. Eng. 21, 357 (2004).

6. F. Talebnia, C. Niklasson, M.J. Taherzadeh, Biotechnol. Bioeng. 90, 345 (2005).

7. S. Blazejak, W. Duszkiewicz-Reinhard, M. Gniewosz, E. RostkowskaDemmer, E. Domurad, Electr. J. Polish Agric. Univer. 5, 1 (2002).

8. A. Bekatorou, A.A. Koutinas, A. Kaliafas, M. Kanellaki, Process Biochem. 36, 549 (2001).

9. M. Abadias, A. Benabarre, N. Teixido, J. Usall, I. Viñas, Int. J. Food 
Microbiol. 65, 173 (2001).

10. M. Kierstan, C. Bucke, Biotechnol. Bioeng.19, 387 (1977).

11. S.V. Ramakrishna, R.S. Prakasham, Current Science 77, 87 (1999).

12. R. Willaert, V.A. Nedovic, J. Chem. Technol. Biotechnol. 81, 1353 (2006).

13. A. Martinsen, G. Skjak-Break, O. Smidsrod, Biotechnol. Bioeng. 33, 79 (1989).

14. G. Skjak-Break, E. Murans, S. Paoletti, Biotechnol. Bioeng. 33, 90 (1989).

15. A. Martinsen, I. Storro, G. Skjak-Break, Biotechnol. Bioeng. 39, 186 (1992).

16. B.S. Yadav, U. Rani, S.S. Dhamija, P. Nigam, D.J. Singh, Basic. Microbiol. 36, 205 (1996).

17. S.H. Cheong, J.K. Park, H.N. Chang, J. Korean Inst. Chem. Eng. 31, 788 (1993).

18. K. Yamagiwa, Y. Shimizu, T. Kozawa, M. Onodera, A. Ohkawa, J. Chem Eng. Japan, 25, 723 (1992).

19. K. Yamagiwa, Y. Shimizu, T. Kozawa, M. Onodera, A. Ohkawa, J. Chem. Eng. Japan, 26, 449 (1993).

20. Yamagiwa, Y. Shimizu, T. Kozawa, M. Onodera, A. Ohkawa, Biotechnol. Tech. 8, 271 (2004).

21. B. Ruggeri, G. Sassi, V. Specchia, F. Bosco, M. Marzona, Process Biochem. 21, 331 (1991).

22. M. Nagashima, M. Azuma, S. Noguchi, K. Inuzuka, Biotechnol. Bioeng. 26, 992 (1984).

23. R. Iamuna, S.V. Ramakrohna, Biomass Bioenergy, 3, 117 (1992).

24. J. Zhao, L. Xia, Fuel Proc. Technol. 90, 1193 (2009).

25. K. Hoyer, M. Gable, G. Zacchi, J. Chem. Technol. Biotechnol. 84, 570 (2009).

26. G. Najafpour, H. Younesi, K.S.K Ismail, Bioresour. Technol. 92, 251 (2004)

27. C.Z. Liu, F. Wang, F.O. Yang, Bioresour. Technol. 100, 878 (2009).

28. E. Araque, C. Parra, M. Rodríguez,J. Freer, J. Baeza, Enzyme Microb. Technol. 43, 120 (2008).
29. A. Ferraz, J. Rodríguez, J. Freer, J. Baeza, Bioresour. Technol. 74, 201 (2000).

30. M.J. Taherzadeh, K. Karimi, BioResources. 2, 472 (2007).

31. J. Szczodrak, J. Fiedurek, Biomass. Bioenerg. 10, 367 (1996).

32. A. Demirbas, Energ. Source. 27, 327 (2005).

33. W.J. Frederick Jr., S.J. Lien, C.E. Courchene, N.A. DeMartini, A.J. Ragauskas, K. Iisa, Bioresour. Technol. 99, 5051 (2008).

34. Q. Wen-tao, Y. Wei-ting, X. Yu-bing, M. Xiaojun, Biochem Eng J. 25, 151 (2005)

35. G. Junter, L. Coquet, S. Vilain, T. Jouenne, Enzyme Microb Tech. 21, 201 (2002).

36. A, Muhammad, Thesis Islamia University, Bahawalpur-Pakistan, 2002.

37. NIST/SEMATECH e-Handbook of Statistical Methods. http://www.itl. nist.gov/div898/handbook/, 24-02-2011.

38. S. Monavari, M. Galbe, G. Zacchi, Biotechnology for Biofuels 2, 1 (2009). http://www.biotechnologyforbiofuels.com/content/2/1/6.

39. B. Chauhan, R. Gupta, Proces Biochem. 39, 2115 (2004).

40. J. Söderström, L. Pilcher, M. Galbe, G. Zacchi, Biomass Bioenerg. 24, $475(2003)$

41. K. Stenberg, M. Bollók, K. Réczey, M. Galbe, G. Zacchi, Biotechnol. Bioeng. 68, 204 (2000)

42. L. Jamai, K. Sendide, K. Ettayebi, F. Errachidi, O. Hamdouni-Alami, A. Tahri-Jouti, T. McDermoth, M. Ettayebi, Fems Microbiol Lett. 204, 375 (2001).

43. J.C. Ogbonna, Y. Amano, K. Nakamura, J. Ferment. Bioeng. 2, 92 (1989).

44. A. Esteghlalian, A.G. Hashimoto, J.J. Fenske, M.H. Penner, Bioresour. Technol. 59, 129 (1996).

45. S. Tian, X.L. Luo, X.S. Yang, J.Y. Zhu, Biorseour. Technol. 101, 8678 (2010)

46. A. Berrocal, J. Baeza, J. Rodríguez, M. Espinosa, J. Freer, J. Chil. Chem. Soc.49 (3), 251 (2004) 